\title{
The Americans' Higher-Law Thinking Behind
}

\section{Higher Lawmaking}

\author{
Joyce Appleby ${ }^{\dagger}$
}

Bruce Ackerman's We The People: Transformations ${ }^{1}$ is elegantly conceived, theoretically clever, rhetorically inventive, and empirically convincing, but it remains ideologically inadequate. It is not underdeveloped but rather inattentive to the formal ideas that construct a society's sense of reality and the plane of informal cues, hints, and symbols that mobilize moral fervor. This neglect disconnects his thesis about higher lawmaking from the higher-law thinking that has distinguished politically alert Americans since the Declaration of Independence.

In the absence of attention to how people in the United States have come to think about a higher law, Ackerman has fallen back on a Whiggish view where love of liberty and justice is assumed to be part of the human endowment, at least of American humans. Fused convictions about democratic governance and liberal aspirations motivate Ackerman's We the People. His conception of their intentions resembles an ascending escalator, carrying the American public ever higher, even if they get off for long spells to meander through cookware and sporting equipment. This Whiggish overlay upon the argument of Transformations appears most strikingly in the discussion of Reconstruction, in which all acts are optimized-whether those of intransigent Radical Republicans or white supremacist Southern Redeemers. Some higher force is orchestrating this partisan cacophony into a melodious resolution.

Historians with their fact-mongering usually play the spoiler at interdisciplinary conferences, but I prefer to eschew that dull role to taste of the nectar of social science schema. I want to share in the categorical capers and morphological madness by adumbrating some of my own. I will pose the proposition that two higher law concepts have polarized American politics from Alexander Hamilton through Ronald Reagan, and that they need to be put into the picture of Ackerman's grand transformative moments. But first a word from my sponsor: the specialists in early

$\dagger$ Professor of History, UCLA.

1. 2 BRUCE ACKERMAN, We the PEOPLE: TRANSFORMATIONS (1998). 
American history. Whether or not colonial Americans had a predisposition towards higher-law thinking, they acquired one in their campaign to avoid taxation without representation. The positivist claim of the British Parliament to be the sole determiner of the rights of Englishmen decisively pushed American polemicists-including the drafters of the Declaration of Independence-towards affirming a higher law and thus introduced a tradition that the Framers of the Constitution and its first interpreters only strengthened.

The two higher laws that have mobilized the moral and intellectual loyalties of America's political participants have been the higher law of conscience and the higher law of nature. Although less familiar, the higher law of conscience animated the Federalists who initiated our constitutional regime. For them, English natural rights represented a learned discourse going back to the Stoics. They liked the English variant of this theory in which rights had been extracted as concrete concessions from the crown, their implementation depending upon common-law procedures. ${ }^{2}$

Federalists drew their political truths from a kind of secular Calvinism, an amalgam of wisdom drawn from the classics, the Bible and English history: Men are prone to sin and society subject to degenerative diseases; only well-crafted constitutions, taking into account these truths, can engage the consciences of society's worthies. The special nature of the United States lay not in signaling a new dispensation for the human race, but in offering enlightened statesmen an opportunity to do a better job of applying the lessons of the past. When the American colonies separated from Great Britain, they freed themselves from the Mother Country's corruption, but not from the pure model itself. History taught the Federalists that order preceded and conditioned liberty and that gentlemen, filtered from the mass of the voters, were the natural protectors of a constitutional order. ${ }^{3}$

Political self-fulfillment came from public service. The Federalist officeholders certainly extolled personal freedom, but it was bounded. When men sought to throw off authority, it was the Old Nick speaking through them. They drew from the Enlightenment a guarded optimism about self-government, hopeful that Americans working at the different political levels could nurture the qualities in its citizens that would sustain a republic. When Alexander Hamilton spoke for a broad construction of the Necessary and Proper Clause, he assumed that an elite of the meritorious would run the national government. ${ }^{4}$ Brilliant in financial matters, he

2. See STANLEY ElKINS \& ERIC MCKITRICK, THE Age OF FEDERALISM 77-131 (1993).

3. See JOYCE APPLEBY, LIBERALISM AND REPUBLICANISM IN THE HISTORICAL Imagination 188-209 (1992); ZolTaN HARASZTI, JOHN ADAMS AND THE PROPHETS OF PROGRESS 139-55 (1964).

4. See ELKINS \& MCKITRICK, supra note 2, at 229-37. 
dismissed the idea of a self-regulating economy as one of the wild chimeras spawned by revolutionary enthusiasm. ${ }^{5}$

Guiding, stabilizing, consolidating the nation through good government, the Federalist leaders also acted on the higher law of conscience when they played a prominent part in initiating the antislavery campaigns that led to gradual abolition in Pennsylvania, New York, and New Jersey. From among their ranks came the judges who brought slavery to a quicker end through judicial decisions in New England. More concerned with justice than achieving equality, they opposed slavery as simply wrong. Far less likely to exalt rights to a realm outside of society, the Federalists stressed the primacy of public order and welfare along with the necessity of the leadership of the virtuous. ${ }^{6}$

The higher law of conscience flourished in the presence of a lively sense of God's judgment as construed in the mainline churches of Congregationalists, Presbyterians, and Episcopalians. New England furnished its seedbed, and migrating New Englanders carried a strong aversion to disorder and injustice along with them to the Midwest. Confident in purposeful human action when informed by right reason and good morals, those who acted out of the higher law of conscience provided the leadership for most of America's ardent efforts at social reform in the first four decades of the nineteenth century. As ministers they staffed the Benevolent Empire, that complex of national associations dedicated to converting, educating, and reforming the American public.?

Jefferson's lines about the self-evident truths that all men are created equal and endowed by their creator with the inalienable rights of life, liberty, and the pursuit of happiness resonated differently through the minds of a wide variety of Americans. Jefferson and his followers divined a higher law of nature in them. By no means self-evident, the Jeffersonian understanding of "the Laws of Nature and of Nature's God" relied upon the radical transformation of thoughts about nature effected by Bacon, Newton, and Locke-Jefferson's "three greatest of all great men." 8 Popularized by the philosophs of the Enlightenment, Jefferson's higher law stressed that nature offered a guide to human affairs-that in fact in the orderliness of nature and the uniformity of cause and effect relationships, human beings could reform the social environment. The design evident in nature pointed to the possibility of a natural harmony if the latent human

5. 3 Alexander Hamilton, The Papers of AleXander Hamilton 76 (Harold C. Syrett \& Jacob E. Cooke eds., 1961).

6. See generally DONALD L. ROBINSON, SLAVERY IN THE STRUCTURE OF AMERICAN POLITICS, 1765-1820 (1971).

7. See John L. Hammond, The Politics of Benevolence (1979); JeAn V. Matthews, TOWARDS A NEW SOCIETY: AMERICAN THOUGHT AND CULTURE (1991).

8. See 14 THOMAS JeFFerson, THE PAPERS OF THOMAS JeFFERSON 56 (Julian P. Boyd ed., 1950). 
potential was liberated from its long imprisonment by patriarchs, prelates, and magistrates. ${ }^{9}$

Those who rallied to the higher law of nature distrusted government, seeing in its officials a propulsive drive towards power and authority that infantilized those without power. Thomas Paine introduced Common Sense with a distinction between society and government, the first a domain of freedom produced by our wants, the latter a regime of restraint necessitated by our wickedness: "Society in every state is a blessing, but government, even in its best state, is but a necessary evil; in its worst state an intolerable one...." Hardly an innocuous idea, the belief in the laws of nature inspired the dismantling of society's hierarchies so that men (and alas, it was strictly speaking, men), long alienated from their true natures, might recover them. Enjoying the reflected glory of the brilliant philosophers who cracked nature's code, believers in the higher law of nature were reformers. For Jefferson, like Thomas Paine, the implementation of natural rights required radical surgery on the traditional body politic. More urgently, the burden of old ways of thinking, of antediluvian conceits, of controlling institutions had to be shed. Only liberation from archaic authorities of all kinds, in their view, would lift the dead hand of the past off the shoulders of the present generation, freeing its members to pursue the progressive possibilities of human enterprise. ${ }^{11}$

As the higher law of nature was being elaborated into a political discourse in the United States, others were detaching economic life from that of politics and reconstituting it as an independent area of inquiry. Because the natural order was independent of the will of communities and their members, it offered an alternative to an authoritative appeal to conscience or justice. The human task now was to bring social ways into conformity with natural tendencies, a particularly radical proposition when applied to the economy. The invisible hand of the market presumably would be a far better guide than a body of law. The transactions of market participants were construed to be as predictable as natural phenomena, and hence susceptible to scientific investigation.

No one subscribed more totally to belief in the improvability of the human mind than Jefferson. For him, almost every moral question contained a scientific solution. The human follies that drove others to rely on a higher law of conscience backed by just authority seemed wrongheaded if not merely old-fashioned to him. Writing to the French Economist

9. See Charles A. Miller, JefFerson aNd NATURE: AN INTERPRETATION (1988); JEFFERSONIAN LEGACIES (Peter Onuf ed., 1950).

10. THOMAS PAINE, COMMON SENSE, THE Rights OF MAN, AND OtHeR EsSENTIAL WRITINGS OF THOMAS PAINE 24 (1969).

11. See Joyce appleby, Without Resolution: The Jefrersonian Tension IN AMERICAN NATIONALISM (1991). 
J.B. Saye, he dismissed the Malthusian formulas that suggested that nature would lead human beings to breed more rapidly than they could feed themselves, with the airy line that "so invariably do the laws of nature create our duties and interests, that when they seem to be at variance, we ought to suspect some fallacy in our reasonings." 12

Inherently more appealing to the young and ambitious and those not seared by the Puritan sense of human flaws, the higher law of nature originally found its believers principally outside of New England, especially in the South and West. Immigrants have tended to fear the moralistic edge of those American leaders summoning a higher law of conscience to their legislative tasks and hence been drawn to the higher law of nature. Similarly Christian denominations in the sectarian moldBaptists especially - viewed limited government as a natural protection to religious freedom, although recently they have abandoned their historic "strict separation" stance to pursue antiabortion and school prayer initiatives. Politicians invoking the higher law of nature have tended to be more negative than positive-anti-tariff, anti-temperance, anti-bank, antiUN, and anti-federal aid to education, but early and late they have been enthusiastic supporters of expansion. ${ }^{13}$

As in Ackerman's concept of dualistic government, Americans do not always operate under the sway of higher law thinking. Generally, they find the zealots promoting either higher law theory intrusive bores, but the crises that have marked the nation's history have recalled citizens of the United States to a faith in one of the two moral orientations. The original Federalists did not appeal to a higher law of conscience when arguing for the ratification of the Constitution. It was only the emergence of an unexpected opposition to George Washington's administration, coinciding with a violent turn in the French Revolution, that sent them scrambling for their Bibles and their histories, the sources for their higher law dicta. In the eyes of the Federalists, French atheism threatened to infect the American body politic. They saw radical conspiracies to undermine all Christian sense of order abounding and viewed unregulated association and free speech as invitations to chaos. ${ }^{14}$

Against the Federalist fulminations, the Jeffersonians articulated the higher law of nature, larding their oratory with references to progress, equality, a new age of revolution and the need to be vigilant against would-

12. 11 ThOMAS JEFFERSON, Writings OF JEFFERSON 2-3 (A.A. Lipscomb \& A.E. Bergh eds., 1903).

13. See Jean H. Baker, AfFairs of Party: The Political Culture of Northern DEMOCRATS IN THE MID-NINETEENTH CentURY (1893); WILLIAM G. MCLOUGHLIN, NEW ENGLAND DISSENT, 1630-1833: THE BAPTISTS AND THE SEPARATION OF CHURCH AND STATE (1971).

14. See James Morton Smith, The Sedition Law, Free Speech and the American Political Process, 9 WM. \& MARY Q. 497 (1952). 
be aristocrats bent on reestablishing colonial deference. They triumphed in 1800 with the election of Jefferson. Jefferson and his successors abided by the higher law of nature, presiding over a people overflowing with individual initiative and unsuppressed energy. Looking back on his first year as President, Jefferson made clear the dangers of energetic government:

The path we have to pursue is so quiet that we have nothing scarcely to propose to our Legislature. A noiseless course... unattractive of notice, is a mark that society is going on in happiness. If we can prevent the government from wasting the labors of the people, under the pretense of taking care of them, they must become happy. ${ }^{15}$

Not until the 1830s did the higher law of conscience enjoy a resurgence of power, for, as Henry Adams said of his forebears, "slavery threw the men and women of New England back on their Puritan origins." ${ }^{16}$ In the ensuing decades the abolitionists demonstrated their commitment to a higher law of conscience by publicly burning the Constitution because it tolerated the institution of slavery. Not an abolitionist, but a foe of the expansion of slavery, Abraham Lincoln repeatedly invoked conscience to stir the sluggish morality of a people grown complacent about the South's "peculiar institution." The ensuing Civil War elaborated most fully the natural law of conscience complete with blood sacrifices, battle hymns, and hallowed ground for commemorations.

The arduous effort to deconstruct the rigid racial hierarchy within Southern society, known to us as Reconstruction, exhausted the collective American conscience by 1876 . The higher law of nature then enjoyed a resurgence of popular support, this time fortified by Charles Darwin's powerful explanation of the origins of all species. The higher law of nature provided the imagery and explanatory tropes for fending off political intrusions into the realm of free bargaining. This bias towards an unregulated economy attracted the support of Northern industrialists who flourished after the Civil War. They no doubt feared that those inspired by a higher law of conscience might impose unwelcome responsibilities and restraints. Darwinian nature could also be interpreted to confer upon them the distinction of being "the fittest" who naturally survived.

The largely unregulated economy, dramatically transforming American society, created its own social problems. The exploitation of vulnerable members of society excited a whole new generation of reformers, drawing struggling farmers and poverty-stricken laborers to begin to speak the

15. 3 THOMAS JEFFERSON, supra note 12 , at 342 .

16. HENRY ADAMS, THE EDUCATION OF HENRY ADAMS 48 (1907). 
language of a higher law of conscience. The Progressive movement embodied the old verities of order and justice made more potent at the dawn of the twentieth century by a supplemental appeal to science, this time to the techniques and knowledge of the expert. From the point of higher law thinking, the New Deal is best seen as an extension of the Progressives, though the ballast from its white supremacist Southern constituency made smooth sailing with a conscience embedded in justice difficult.

In our own time, Reaganite conservatives reasserted the higher law of nature, returning the tradition to its Southern base and its Baptist outsider mentality. More consistent than parties, regions have held true to their original higher law predispositions, the West furnishing the preponderance of advocates of the higher law of nature and New England and the Northwest harboring those for whom politics is inseparable from conscience. This regional matrix for the higher law of nature may account for the ease with which Democrat Bill Clinton took over the Republican agenda in 1994. Only time will tell if Americans will rally to a reassertion of the higher law of conscience, but as with Bruce Ackerman's higher law making, events act as prompters, leaving decades of American political life free of the sturm und drang of higher law thinking. But unlike Ackerman's scheme where an undifferentiated "We the People" ratifies higher lawmaking, the two higher laws that have polarized American political values have contended for popular support, often provoking as much opposition as assent, suggesting that higher lawmaking will always be problematic in a social plant with the tangled cultural roots of the United States. 
